\title{
Coordination of platinum therapeutic agents to met-rich motifs of human copper transport protein $1 \dagger$
}

\author{
Sarah E. Crider, Robert J. Holbrook and Katherine J. Franz* \\ Received 17th August 2009, Accepted 23rd October 2009 \\ First published as an Advance Article on the web 2nd November 2009 \\ DOI: $10.1039 / b 916899 k$
}

\begin{abstract}
Platinum therapeutic agents are widely used in the treatment of several forms of cancer. Various mechanisms for the transport of the drugs have been proposed including passive diffusion across the cellular membrane and active transport via proteins. The copper transport protein $\mathrm{Ctr} 1$ is responsible for high affinity copper uptake but has also been implicated in the transport of cisplatin into cells. Human hCtrl contains two methionine-rich Mets motifs on its extracellular $\mathrm{N}$-terminus that are potential platinum-binding sites: the first one encompasses residues 7-14 with amino acid sequence Met-Gly-Met-Ser-Tyr-Met-Asp-Ser and the second one spans residues 39-46 with sequence Met-Met-Met-Met-Pro-Met-Thr-Phe. In these studies, we use liquid chromatography and mass spectrometry to compare the binding interactions between cisplatin, carboplatin and oxaliplatin with synthetic peptides corresponding to hCtr1 Mets motifs. The interactions of cisplatin and carboplatin with Met-rich motifs that contain three or more methionines result in removal of the carrier ligands of both platinum complexes. In contrast, oxaliplatin retains its cyclohexyldiamine ligand upon platinum coordination to the peptide.
\end{abstract}

\section{Introduction}

The $90 \%$ survival rate of patients with testicular cancer highlights the effectiveness of the widely used chemotherapy drug cisplatin, cis-diamminedichloro-platinum(II). ${ }^{1}$ Although cisplatin and later-generation $\mathrm{Pt}$ drugs carboplatin and oxaliplatin (see Chart 1) are also used against other cancers, several drawbacks limit the survival rate observed in testicular cancer. In many cases, treatment is diminished by side effects of nephrotoxicity and neurotoxicity, as well as inherent and acquired resistance of many cancer types to this class of drug. Understanding the molecular basis for resistance is critical to discovering new treatment regimens in order to expand the effectiveness of these drugs.

Cisplatin is administered as a formulation that includes $154 \mathrm{mM} \mathrm{NaCl}$ that suppresses hydrolysis of the chloride ligands from platinum. The high chloride ion concentration in the blood $(\sim 105 \mathrm{mM})$ presumably allows cis-[ $\left.\mathrm{Pt}\left(\mathrm{NH}_{3}\right)_{2} \mathrm{Cl}_{2}\right]$ to remain neutral until in enters the cytosol. Here it encounters a $4 \mathrm{mM}$ chloride ion concentration which facilitates hydrolysis of the chloro ligands to form aquated $\left[\mathrm{Pt}\left(\mathrm{NH}_{3}\right)_{2}\left(\mathrm{OH}_{2}\right) \mathrm{Cl}\right]^{+}$, $\left[\mathrm{Pt}\left(\mathrm{NH}_{3}\right)_{2}(\mathrm{OH}) \mathrm{Cl}\right],\left[\mathrm{Pt}\left(\mathrm{NH}_{3}\right)_{2}\left(\mathrm{OH}_{2}\right)_{2}\right]^{2+}$, and $\left[\mathrm{Pt}\left(\mathrm{NH}_{3}\right)_{2}(\mathrm{OH})_{2}\right]$ species. The aquo and hydroxo forms are more reactive towards nucleophiles than the original chloro species, and upon entering the nucleus they bind to $\mathrm{N} 7$ positions on adjacent guanine bases of DNA. These intrastrand DNA cross-links are the primary biological targets that lead to cell death. ${ }^{1}$

Department of Chemistry, Duke University, Durham, NC 27708-0346, USA. E-mail: katherine.franz@duke.edu; Fax: +1919-660-1605;

Tel: +1 919-660-1541

$\dagger$ Electronic supplementary information (ESI) available: Calculated mass spectra and additional chromatography traces. See DOI: $10.1039 / \mathrm{b} 916899 \mathrm{k}$
Any side reaction that diverts the $c i s-\mathrm{Pt}\left(\mathrm{NH}_{3}\right)_{2}{ }^{2+}$ core from forming these toxic lesions on DNA is a potential pathway for drug inactivation, increased side effects, or resistance. Such pathways include inactivation of the Pt compounds by sulfur-containing molecules like glutathione, increased repair of the cell-killing Pt-DNA adducts, and decreased drug accumulation. ${ }^{2}$ Of these mechanisms, the decreased accumulation of Pt drugs is the most common defect found in resistant cells and therefore demands critical attention in order to maximize the effectiveness of this well proven class of drugs across a wider range of cancer types.

Observations that cisplatin uptake is not saturable, does not have a $\mathrm{pH}$ optimum, and is not inhibited by structural analogs lead to the long-standing hypothesis that cisplatin passively diffuses across cell membranes. ${ }^{1}$ While passive diffusion remains a viable mechanism for Pt drug entry, current

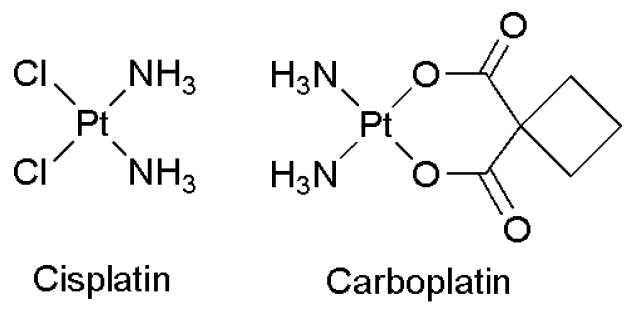<smiles>O=C1O[P]2(N[C@H]3CCCC[C@H]3N2)OC1=O</smiles>

Chart 1 Clinically important Pt drugs. 
estimates suggest that only half of Pt drug uptake is via passive diffusion, while the remainder enters by other transport mechanisms that are only beginning to be discovered and appreciated. ${ }^{3,4}$ One of these is the cell-surface copper transport protein $\mathrm{Ctr} 1 .^{5}$

Increasing and compelling evidence is revealing that cellular processes associated with $\mathrm{Cu}$ homeostasis are modulating $\mathrm{Pt}$ accumulation, particularly in resistant cells. ${ }^{6}$ A connection between $\mathrm{Cu}$ and $\mathrm{Pt}$ trafficking was suggested by observations of bidirectional cross-resistance of $\mathrm{Pt}$ drugs and $\mathrm{Cu}$ in a variety of cell lines. ${ }^{5,7}$ Cells selected for resistance to high levels of $\mathrm{Cu}$ were found to be resistant to Pt drugs; likewise, highly Pt-resistant cell lines were found to be moderately resistant to $\mathrm{Cu}^{8}$ The cytotoxic properties of these two metals are quite different, implying that their similar phenotype derives from impairment in shared uptake or efflux mechanisms. Work in yeast and mammalian cells identified the shared uptake mechanism as the transmembrane copper transporter Ctr $1,{ }^{9}$ and both ATP7A and ATP7B, two structurally similar $P$-type ATPases that mediate $\mathrm{Cu}$ efflux from mammalian cells, have been implicated in removing Pt drugs from cells. ${ }^{5,7,10,11}$

Yeast cells in which the CTR1 gene is deleted show increased resistance to cisplatin that correlates with reduced uptake of cisplatin and reduced formation of the critical Pt-DNA adducts compared with control cells. ${ }^{9,12}$ Cisplatin has been shown to induce internalization and degradation of hCtrl as well as impede the cellular uptake of both carboplatin and oxaliplatin. ${ }^{13,14}$ These initial reports clearly establish a biological link between Ctr1 and Pt drugs; however, how cisplatin interacts with $\mathrm{Ctrl}$ and how the two molecules modulate each other's trafficking and function is unclear. Recent work from the Howell lab using murine embryonic fibroblasts in which both CTR1 alleles were deleted indicates that the copper transporter controls cellular accumulation of cisplatin, carboplatin, and oxaliplatin. Subsequently, Howell et al. observed that oxaliplatin at higher concentrations may use a different cellular entry mechanism. ${ }^{15}$ In addition to these conventional mononuclear $\mathrm{Pt}$ drugs, an experimental polynuclear Pt compound BBR3464 has also been demonstrated to utilize hCtr1 to gain cellular access. ${ }^{16}$

Studies of a variety of human cell lines in which hCtr1 is over-expressed reveal that simply increasing the level of hCtr1 does not always correlate with an increase in cell death by Pt drugs. For example, human ovarian carcinoma cells engineered to over-express hCtr1 accumulate more $\mathrm{Pt}$ than their counterparts, but this over-accumulation does not lead to increased Pt-DNA adducts or cisplatin sensitivity. ${ }^{7}$ This implies that not all Pt drugs brought in via a Ctr1-mediated pathway reach their DNA target. Not all cisplatin-resistant cell lines show reduction in endogenous Ctr1 expression levels compared with cisplatin-sensitive counterparts. ${ }^{17}$ Similarly, at least one Pt-resistant cell line, a cervix squamous cell carcinoma, does not accumulate increased levels of cisplatin when it is engineered to over-express hCtr $1 .{ }^{18}$ However, because it is not clear that over-expressed Ctr1 functions normally in human cells, it is not at all obvious that its forced over-expression should be expected to lead to an increase in $\mathrm{Pt}$ accumulation. ${ }^{15}$
More conflicting results describe the trafficking of Ctr1 in the presence of Pt drugs. In human ovarian carcinoma cells that endogenously or exogenously express hCtr1, cisplatin causes rapid disappearance of the transporter from the plasma membrane, suggesting that cisplatin down-regulates its own transporter in these cells. ${ }^{19}$ On the other hand, Ctr1 expressed in human embryonic kidney cells is stabilized at the plasma membrane as a multimeric complex, and is not endocytosed or degraded upon Pt treatment. ${ }^{20}$ These seemingly conflicting results expose the need to more fully understand the factors governing $\mathrm{Pt}$ drug access to cells in general and $\mathrm{Pt}-\mathrm{Ctr} 1$ interactions in particular.

Human hCtrl contains three transmembrane regions that situate the amino terminus on the extracellular side with the carboxyl terminus facing the cytosol. ${ }^{21-24}$ The protein likely exists as a homotrimer in its active form..$^{21,25-27}$ The unique feature of the amino-terminal region of Ctr1, which is the first gate of entry for cellular copper, is the presence of methioninerich domains arranged as MXXM or MXM motifs containing 3-5 methionine residues per "Mets" motif. Yeast yCtr1 has 8 Mets motifs, with a total of 30 methionine residues in the $\sim 140$-residue extracellular domain, whereas human hCtr 1 has two Mets motifs in a 65-residue extracellular region.

The extracellular N-terminal region of Ctr1 is critical for Ctr1-mediated Pt drug entry into cells. Pt drug accumulation studies with hCtr1 deletion mutants show that full-length and C-terminally truncated protein both transport Pt drugs, whereas an N-terminal deletion mutant fails to do so. ${ }^{17,28}$ The N-terminal Mets motifs were also found to be responsible for stabilizing multimeric hCtrl at the plasma membrane in HEK cells expressing hCtr1. ${ }^{20}$ Mutagenesis of the eight methionines that make up the two Mets motifs of hCtr1 to alanines results in protein that appropriately traffics to the plasma membrane but does not trimerize upon cisplatin exposure, suggesting that the stable trimers observed in the parent protein result from cisplatin cross linking adjacent proteins via methionine binding. Further evidence for this model is provided by the fact that trimer formation is reversed upon exposure to Pt chelating compounds. ${ }^{20}$ A study that used fluorescent fusion proteins to monitor molecular dynamics of yCtr1 found that $\mathrm{Cu}(\mathrm{I})$ induced FRET but that cisplatin, which accumulated in a Ctr1-dependent manner, did not. ${ }^{28}$ This result highlights the fact that differences in the chemistry of copper and platinum translate into differences in metalinduced protein conformational changes and mechanisms of metal transport by Ctr1.

Several lines of evidence point to $\mathrm{Cu}(\mathrm{I})$ as the active redox state for $\mathrm{Ctr} 1,{ }^{21,26,29-31}$ and we have previously shown that isolated Mets domains are capable of binding $\mathrm{Cu}(\mathrm{I})$ selectively over $\mathrm{Cu}(\mathrm{II}) .{ }^{32}$ Additionally, yCtr1 is unable to transport $\mathrm{Zn}$ (II) or other divalent metal ions but readily takes in $\operatorname{Ag}(\mathrm{I})$ as a surrogate for $\mathrm{Cu}(\mathrm{I}) .^{27}$ Given the fact that $\mathrm{Ctr} 1$ does not transport divalent metal ions and that it seems to be ideally suited for transporting soft, kinetically labile, monovalent cations, it would actually be quite surprising that this protein transports intact $\mathrm{Pt}$ (II) coordination compounds. Apart from the fact that both $\mathrm{Cu}(\mathrm{I})$ and $\mathrm{Pt}(\mathrm{II})$ prefer soft, sulfur-rich coordination environments, their coordination chemistry otherwise is quite different. Whereas $\mathrm{Cu}(\mathrm{I})$ can adopt linear, 
trigonal, or tetrahedral coordination geometries, $\mathrm{Pt}(\mathrm{II})$ is rigorously square planar. In addition, the ligands on $\mathrm{Pt}(\mathrm{II})$ are less likely to be kinetically labile, although inner-sphere ligand exchange reactions can occur, with their likelihood depending on the trans effect of the ligands.

The affinity of $\mathrm{Pt}(\mathrm{II})$ for sulfur-containing ligands has provoked a long-standing question of how Pt drugs reach their DNA targets in spite of significant competition for binding to $\mathrm{S}$-containing amino acids and proteins. ${ }^{33,34}$ Because neuro- and nephrotoxicity associated with Pt drug treatment has been attributed to S-containing proteins, and because intracellular S-containing compounds like glutathione may act as intracellular drug reservoirs, ${ }^{33}$ numerous studies have been done to describe the interactions of simple amino acids like cysteine, methionine, and glutathione with various $\mathrm{Pt}(\mathrm{II})$ compounds. $^{35-42}$ These studies have revealed that the thioether of methionine can displace chloro or aqua ligands of cisplatin. Thioether sulfur has a strong trans influence, therefore methionine coordination to square-planar cisdiaminePt(II) core can result in loss of the amine ligand trans to the incoming thioether. Many model studies have used stable tridentate chelates of diethylenetriamine (dien) in order to suppress ligand loss and focus exclusively on the $\mathrm{Pt}-\mathrm{S}$ bonding interaction. ${ }^{4-49}$ However, the potential replacement of the pendant ligands on Pt drugs will have important repercussions on the mechanism of action of Ctr1-transported $\mathrm{Pt}$, since the cis-diamminePt(II) core is the active metal complex that binds to DNA to affect its cytotoxic action. Therefore we focus here exclusively on the interactions of hCtrl peptides with the clinically important drugs themselves. Methionine-platinum adducts are not unique to human Ctr1 species as work by Arnesano et al. have shown that in the presence of a methionine-rich sequence of yCtr1, cisplatin is stripped of its ligands and binds in a $1: 1$ ratio. ${ }^{50,51}$

Certain Pt(II) complexes selectively hydrolyze peptide amide bonds by first anchoring onto Met or His side chains. ${ }^{52-54}$ Cisplatin is included in this family of inorganic hydrolases, and has been shown to cleave the second amide bond upstream from an anchoring Met in relatively simple acetylated di- and tripeptides. ${ }^{55-57}$ These model studies strongly encourage the examination of peptides containing multiple Met residues such as those found in hCtrl to determine if hydrolysis is a possible mechanism of action.

The differences in the coordination chemistry of $\mathrm{Cu}(\mathrm{I})$ and $\mathrm{Pt}(\mathrm{II})$ raise two fundamental questions related to Ctr1mediated Pt drug uptake: (1) What happens to Pt drugs upon interacting with the extracellular domains of Ctr1? Our hypothesis is that methionine residues in the Mets domains induce ligand exchange reactions that change the molecular speciation of the original drug, which has important ramifications for its overall efficacy. (2) How does the interaction of the protein with Pt drugs change the integrity of the protein itself? Given the proclivity of Pt compounds to hydrolyze amide bonds, it is possible that Pt drugs may degrade hCtr1. To gain insight into these questions, we examined the reaction products of model Mets peptides derived from human hCtr1 with $\mathrm{Pt}$ drugs by combined liquid-chromatography-mass spectrometry (LC-MS).

\section{Materials and methods}

\section{Peptide synthesis and purification}

All peptides were synthesized on a Protein Technologies PS3 automated peptide synthesizer using Fmoc-PAL-PEG-PS resin (Applied Biosystems) in a $0.1 \mathrm{mmol}$ scale. Standard Fmoc (9-fluorenylmethoxy-carbonyl)-protected amino acids (Novabiochem) were coupled with HBTU ( $O$-benzyotriazole$N, N, N^{\prime}, N^{\prime}$-tetramethyluronium hexafluorophosphate; Novabiochem) in the presence of $0.4 \mathrm{M}$ NMM ( $N$-methylmorpholine) in DMF ( $N, N^{\prime}$-dimethylformamide) for 20 min cycles. Fmoc deprotection was achieved using $20 \%$ piperidine in DMF. The $N$-termini of all peptides were acetylated with acetic anhydride and NMM. Cleavage and side-chain deprotection of peptides containing methionine were carried out in the reaction vessel using a $7 \mathrm{~mL}$ cocktail of trifluoroacetic acid (TFA) with $100 \mu \mathrm{L}$ triisopropylsilane (TIS) and $150 \mu \mathrm{L}$ ethane dithiol (EDT) for $4 \mathrm{~h}$ with an additional $75 \mu \mathrm{L}$ EDT and $65 \mu \mathrm{L}$ bromotrimethylsilane (TMSBr) added during the final $30 \mathrm{~min}$ of cleavage. For peptides without methionines the cleavage cocktail consisted of TFA:water:TIS $(95 \%: 2.5 \%: 2.5 \%)$ with a cleavage time of $3 \mathrm{~h}$. After evaporation of TFA, the remaining $1 \mathrm{~mL}$ TFA was washed three times with $10 \mathrm{~mL}$ aliquots of cold diethyl ether, air-dried, and lyophilized. The peptides were purified by preparative reverse-phase HPLC on a YMC C18 column $(250 \times 200 \mathrm{~mm}$ I.D. $)$. The masses of all peptides were determined by matrix-assisted laser desorption ionization time-of-flight (MALDI) or electrospray ionization mass spectrometry. For MALDI analysis, samples were suspended in $\alpha$-cyano-4-hydroxycinnamic acid as matrix and examined on a Voyager DE-Pro mass spectrometer.

\section{Peptide incubations with Pt drugs}

A $3 \mathrm{mM}$ stock solution of cis-diamminedichloroplatinum(II) was prepared in $150 \mathrm{mM} \mathrm{NaCl}$ solution. Aqueous stock solutions of carboplatin and oxaliplatin were prepared in concentrations of $4.0 \mathrm{mM}$ and $12.6 \mathrm{mM}$, respectively. Peptide solutions were prepared in $\mathrm{DI} \mathrm{H}_{2} \mathrm{O}$ at varying concentrations, which were determined by using UV-Vis spectroscopy via the absorbance of tyrosine at $275 \mathrm{~nm}$, or absorbance of the amide backbone at $215 \mathrm{~nm}$ and $225 \mathrm{~nm}$. Reaction samples were prepared in a $1: 1$ stoichiometry of $\mathrm{Pt}(\mathrm{II})$ :peptide at $800 \mu \mathrm{M}$ concentration in buffered solutions containing $23.8 \mathrm{mM}$ carbonate, $1.13 \mathrm{mM}$ phosphate and $100 \mathrm{mM} \mathrm{NaCl}$. The $\mathrm{pH}$ of the buffered solutions was adjusted to 7.4 with $0.1 \mathrm{M} \mathrm{HCl}$ or $\mathrm{NaOH}$. Reaction mixtures were incubated at $37^{\circ} \mathrm{C}$ for $24 \mathrm{~h}$. Studies investigating the reversibility were carried out using 10 equivalents of either 3,6-dithia-1,8-octanediol, or triethylenetetraamine, which were incubated with samples for $24 \mathrm{~h}$ prior to analysis via LCMS.

\section{Liquid chromatography mass spectrometry analysis}

All mass spectrometry experiments were performed using an Agilent 1100 SL LC/MSD-Trap instrument in positive ion mode at a rate of 40 or $60 \mu \mathrm{L} \mathrm{min}{ }^{-1}$, a nebulizer pressure of $20 \mathrm{psi}$, a dry gas rate of $7 \mathrm{~L} \mathrm{~min}^{-1}$, and an ionization chamber temperature of $300{ }^{\circ} \mathrm{C}$. Reverse phase LC gradients as well as mobile phases were optimized for each peptide and a Varian 
Polaris $3 \mathrm{u} \mathrm{C18-A} 150 \times 1.0 \mathrm{~mm}$ column was used for all experiments. The gradient for P1 was as follows: 1 min 10\% $\mathrm{B}$, $24 \mathrm{~min} 100 \% \mathrm{~B}, 30 \mathrm{~min} 10 \% \mathrm{~B}$, where mobile phase B contains 97\%:3\% acetonitrile-water with $0.1 \%$ formic acid and $\mathrm{A}$ contains $97 \%: 3 \%$ water-acetonitrile with $0.1 \%$ formic acid. The gradient for all other peptides was: $3 \mathrm{~min} 3 \% \mathrm{~B}, 37 \mathrm{~min}$ $90 \%$ B, 42 min $90 \%$ B, where the mobile phases contains $0.1 \mathrm{mM}$ ammonium acetate in place of formic acid.

\section{Results}

There are two methionine-rich Mets domains found on the extracellular N-terminus of hCtr1; the first one encompassing residues 7-14 with amino acid sequence Met-Gly-Met-SerTyr-Met-Asp-Ser and the second one with residues 39-46 and sequence Met-Met-Met-Met-Pro-Met-Thr-Phe. We therefore chose these two human sequences for our studies. Cisplatin, carboplatin, and oxaliplatin are all 4-coordinate, square planar coordination complexes of $\mathrm{Pt}(\mathrm{II})$, but with different carrier ligands (see Chart 1). Reasoning that the ligandexchange reactions of these various coordination complexes with methionine-rich peptides may be different, we investigated all 3 of these clinically important drugs with one of our methionine-rich peptides.

The names and amino acid sequences of peptides used in this study are shown in Table 1. They were synthesized by standard Fmoc solid-phase peptide synthesis, purified by HPLC, and analyzed by mass spectrometry. Peptide cleavage conditions were optimized to minimize methionine oxidation, which is readily detected by a shift in retention time on HPLC. Stock peptide solutions were periodically checked by HPLC to verify that they remained in the reduced state. The peptides are stable in aqueous solution at room temperature for several days. For storage, samples are kept at $-20{ }^{\circ} \mathrm{C}$ in powder form or frozen aqueous solution. All of the peptides were made with an acetyl cap (Ac) on the N-terminus, an amide at the C-terminus, and a lysine residue added to improve their water solubility. Derivatives of the Mets motifs were also used in this study, where norleucine (Nle), a structural analog of methionine that does not contain sulfur, replaces two or more methionine residues within the peptide sequences.

In order to mimic the extracellular conditions that Pt drugs encounter during drug delivery, we chose a buffer system that contains $23.8 \mathrm{mM}$ carbonate, $1.13 \mathrm{mM}$ phosphate, and $100 \mathrm{mM} \mathrm{NaCl}$ at $\mathrm{pH} \mathrm{7.4}$. The high chloride concentration was included to match that found in blood and to minimize hydrolysis of the chloride ligands on cisplatin. Carbonate is a major component of blood with a total concentration of $\sim 24 \mathrm{mM} .^{15,16}$ This concentration is comprised of an equilibrium of all carbonate forms in the blood including the

Table 1 Model peptides used in this study

\begin{tabular}{llllllllllll}
\hline Name & Description & \multicolumn{1}{c}{ Amino acid sequence } \\
\hline P1 & hCtr1 (7-14 K) & Ac & M & G & M & S & Y & M & D & S & K \\
P1-3N & 3 Met $\rightarrow$ Nle & Ac & Nle & G & Nle & S & Y & Nle & D & S & K \\
P1M7 & Met7 & Ac & M & G & Nle & S & Y & Nle & D & S & K \\
P1M9 & Met9 & Ac & Nle & G & M & S & Y & Nle & D & S & K \\
P2 & hCtr1 (39-46 K) & Ac & M & M & M & M & P & M & T & F & K \\
\hline
\end{tabular}

carbonate ion, bicarbonate, carbonic acid, and dissolved carbon dioxide. Dabrowiak has argued that DNA, protein, and peptide binding studies using buffered solutions without a physiological concentration of carbonate do not take into account the effects that carbonate has on cisplatin's cellular activity. Their work has found that cisplatin forms $\mathrm{Pt}$-carbonato species in a carbonate buffer and that such species are taken up and/or modified by cells. ${ }^{58,59}$ This finding suggests that carbonate platinum species could be responsible for the biological and anticancer activity of cisplatin. All of our studies were therefore done by incubating the peptide and Pt drug in our standard buffer at $37{ }^{\circ} \mathrm{C}$. Aliquots of the reaction mixtures were removed at specified time points and analyzed by LC-MS in order to achieve in-line separation and mass identification of reaction products. A concentration of $800 \mu \mathrm{M}$ peptide was found to be optimal for observing changes in the UV chromatograms. For all studies, 1 equiv. of Pt drug was incubated with the peptides. This concentration corresponds to $240 \mu \mathrm{g} \mathrm{mL}^{-1}$ for cisplatin. Clinical dosing of $\mathrm{Pt}$ drugs varies greatly depending on the cancer type, patient history, route of administration, and individual tolerance, with the highest dosing reaching $200-400 \mathrm{mg} \mathrm{m}^{-2}$ (where $\mathrm{m}^{2}$ is body surface area). ${ }^{60}$ At these doses, total platinum concentration in the plasma has been measured up to $34 \mu \mathrm{g} \mathrm{mL}^{-1}$ within an hour of administration. ${ }^{61}$ The concentrations used in this study are within an order of magnitude of these clinical values.

\section{Reaction of hCtr1(7-14 K) (P1) and Cisplatin}

The reaction of $800 \mu \mathrm{M}$ peptide $\mathrm{P} 1$ incubated with one equiv. of cisplatin in our standard buffer at $37{ }^{\circ} \mathrm{C}$ was monitored over the course of $24 \mathrm{~h}$ via $\mathrm{LC}-\mathrm{MS}$. As shown by the chromatography traces in Fig. 1, the signal for the P1 apo-peptide decreases in intensity over time while several new peaks emerge. After $4 \mathrm{~h}$ of incubation at $37^{\circ} \mathrm{C}$, the intensity of the apo-peptide peak decreases by a third, and two new predominant products appear with elution times at 10 and $11.7 \mathrm{~min}$ and corresponding $\mathrm{m} / \mathrm{z}$ values centered at 1283.6 and 1320.5, respectively. The 1283.6 value is consistent with the mass of the peptide plus a naked platinum(II), which implies that all 4 of the original cisplatin ligands have been replaced by peptidebased ligands. The donor atoms from the peptide are presumably 3 neutral sulfurs from the Met residues plus a deprotonated amide nitrogen from the peptide backbone to give overall a cationic complex $[\mathrm{Pt}(\mathrm{P} 1-\mathrm{H})]^{+}$with a predicted isotope pattern that matches the experimental result (Fig. S1a, ESI $\dagger$ ). Alternatively, the peptide could use two thioethers and two deprotonated amide nitrogens to coordinate $\mathrm{Pt}$ and retain a proton on Lys to accommodate an overall positive charge of indistinguishable mass. The second major product, with $m / z$ centered around 1320.5, is consistent with $\mathrm{Pt}$ (II) bound to the peptide and one $\mathrm{Cl}^{-}$to give $[\mathrm{PtCl}(\mathrm{P} 1)]^{+}$with a predicted isotope pattern that matches the observed spectrum (Fig. S1b, ESI $\dagger$ ). The peptide-based donor atoms in the case are presumably 3 neutral thioether sulfurs.

After $24 \mathrm{~h}$ of reaction time, the peak for the apo-peptide completely disappears, while those corresponding to $\mathrm{m} / \mathrm{z}$ values of 1283.6 and 1320.5 grow in, along with other peaks 


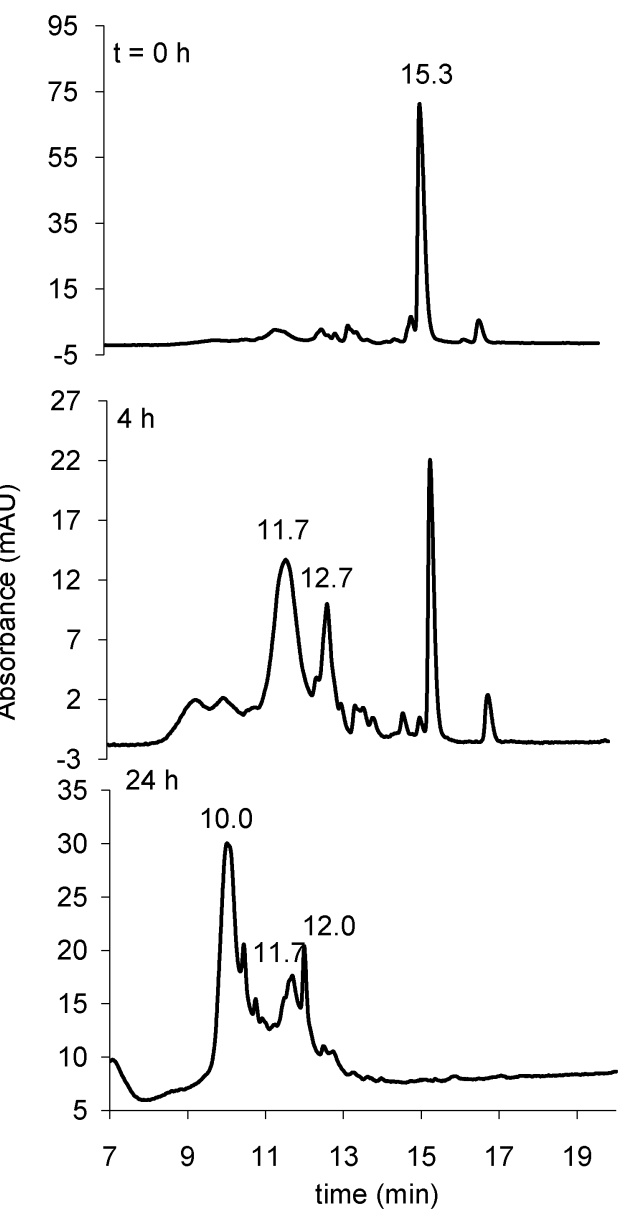

Fig. 1 LC data of $\mathrm{P} 1$ incubated at $37{ }^{\circ} \mathrm{C}$ with 1 equiv. cisplatin at $\mathrm{pH}$ 7.4. Time points 0,4 and $24 \mathrm{~h}$ are pictured with the peak at 15.3 corresponding to the apo-peptide. The species eluting at 10.0 and $11.7 \mathrm{~min}$ have been identified as that of $[\mathrm{Pt}(\mathrm{P} 1-\mathrm{H})]^{+}$, and $[\mathrm{PtCl}(\mathrm{P} 1)]^{+}$, respectively. The calculated and experimental mass spectra are shown in Fig. S1, ESI. $\dagger$ Due to a lack of a mass signal species with a retention time of 12.0 and $12.7 \mathrm{~min}$ were not identified.

that unfortunately do not provide a mass signal. No significant changes are observed between the $4 \mathrm{~h}$ time point and the $24 \mathrm{~h}$ time point, so only the $24 \mathrm{~h}$ trace is shown in Fig. 1.

While several of the products seen forming over the course of $24 \mathrm{~h}$ were unable to be identified by mass spectrometry, their formation was shown to be reversible by the addition of 10-fold excess of 3,6-dithia-1,8-octanediol (DTO) to the reaction mixture. After incubating the reaction mixture with the chelator for $24 \mathrm{~h}$, the LC trace shows regeneration of the apo-peptide signal (Fig. S2, ESI $\dagger$ ). This result indicates that the unidentified products contained Pt-adducts of the full-length peptide and do not correspond to any peptide cleavage products. The reversibility of the formation of platinum adducts in this reaction also indicates that the bond strength of $\mathrm{Pt}-$ methionine is relatively weak compared to that of Pt-DTO.

\section{Norleucine derivative P1-3N}

In order to verify that the interactions of Mets peptides with cisplatin are dependent on the thioether functional groups of the methionine residues, we prepared a 'mutant' peptide in which all 3 methionines are replaced by norleucine (P1-3N). This peptide was incubated at $800 \mu \mathrm{M}$ concentration in a $1: 1$ mixture with cisplatin in our standard reaction buffer. After $24 \mathrm{~h}$ of incubation at $37{ }^{\circ} \mathrm{C}$, the sample was analyzed by HPLC. No new bands are observed in the HPLC trace, and the signal intensity of the band corresponding to apo-peptide is comparable to that of the sample taken at $0 \mathrm{~h}$ (data not shown). Based on these findings it was determined that no reaction occurs between cisplatin and P1-3N and that Met residues are required for peptide-Pt adduct formation.

\section{hCtr1 Nle derivatives P1M7 and P1M9 and cisplatin}

In order to compare how a peptide with a single methionine residue compares with multiple methionine Mets peptides, we simplified our P1 peptide by replacing two of the methionines with norleucine. The P1M7 peptide contains only 1 methionine that corresponds to hCtr1 position 7, while peptide P1M9 contains one methionine that corresponds to hCtr1 position 9. As discussed previously in our studies of the reactivity of P1-3N with cisplatin, the absence of methionine in the P1 sequence prevents the binding of platinum species. Therefore the presence of only one methionine in both P1M7 and P1M9 provides only one anchoring site for cisplatin.

The reactivity patterns and masses obtained for incubations of cisplatin with P1M7 and P1M9 were very similar, so only data for P1M9 are shown in Fig. 2. Within $1 \mathrm{~h}$ of mixing, a new species forms that elutes at $14.6 \mathrm{~min}$ and is distinct from the intact apo-peptide that elutes at $18.5 \mathrm{~min}$. The mass spectrum for the 14.6 min peak, shown in Fig. 2a, is consistent with a $\mathrm{Pt}(\mathrm{II})$ adduct of full-length $\mathrm{P} 1 \mathrm{M} 9$ in which cisplatin has lost one $\mathrm{Cl}^{-}$ligand to leave $\left[\mathrm{Pt}\left(\mathrm{NH}_{3}\right)_{2} \mathrm{Cl}\right]^{+}$. The observed mass spectrum matches that of a spectrum calculated by an isotope distribution calculator and confirms the presence of both $\mathrm{Pt}$ and $\mathrm{Cl}$ in this sample (ESI $\dagger)$. Given the result of the control experiment in which $\mathrm{P} 1-3 \mathrm{~N}$ that contains no methionines fails to react with cisplatin under these same conditions, we conclude that $\mathrm{Pt}$ binds to the lone Met S in P1M9, as indicated pictorially in Fig. 2b.

With further incubation time, several new species appear that become defined after $8 \mathrm{~h}$, as indicated by the chromatogram in Fig. 2a. The mass spectra corresponding to these peaks reveal several $\mathrm{Pt}$-peptide adducts, one of which is shown in Fig. 2c for the species that elutes at 17.3 min with a mass signal centered at 1266 . The isotope pattern of this spectrum is clearly different from the one shown in Fig. 2a and confirms the presence of $\mathrm{Pt}$ and the absence of $\mathrm{Cl}$. The isotope distribution is consistent with $\mathrm{Pt}$ (II) coordinated by one ammine and the full-length P1M9 peptide, which presumably binds via the Met $\mathrm{S}$ and two deprotonated amides, as shown by the chemical drawing in Fig. 2c. The next most abundant peak in this study elutes at $18.1 \mathrm{~min}$ and becomes more prevalent after $24 \mathrm{~h}$ of reactivity. This product has a mass to charge ratio of 1302.1 and corresponds to $\mathrm{P} 1 \mathrm{M} 9$ bound to $\mathrm{PtCl}\left(\mathrm{OH}_{2}\right)^{+}$ (Fig. S3, ESI $\dagger$ ). This species coordinates to both the sulfur of the methionine as well as a deprotonated amide nitrogen in the peptide backbone.

The results of the $\mathrm{P} 1 \mathrm{M} 7$ and $\mathrm{P} 1 \mathrm{M} 9$ cisplatin reactions confirm our hypothesis that at least one methionine residue 

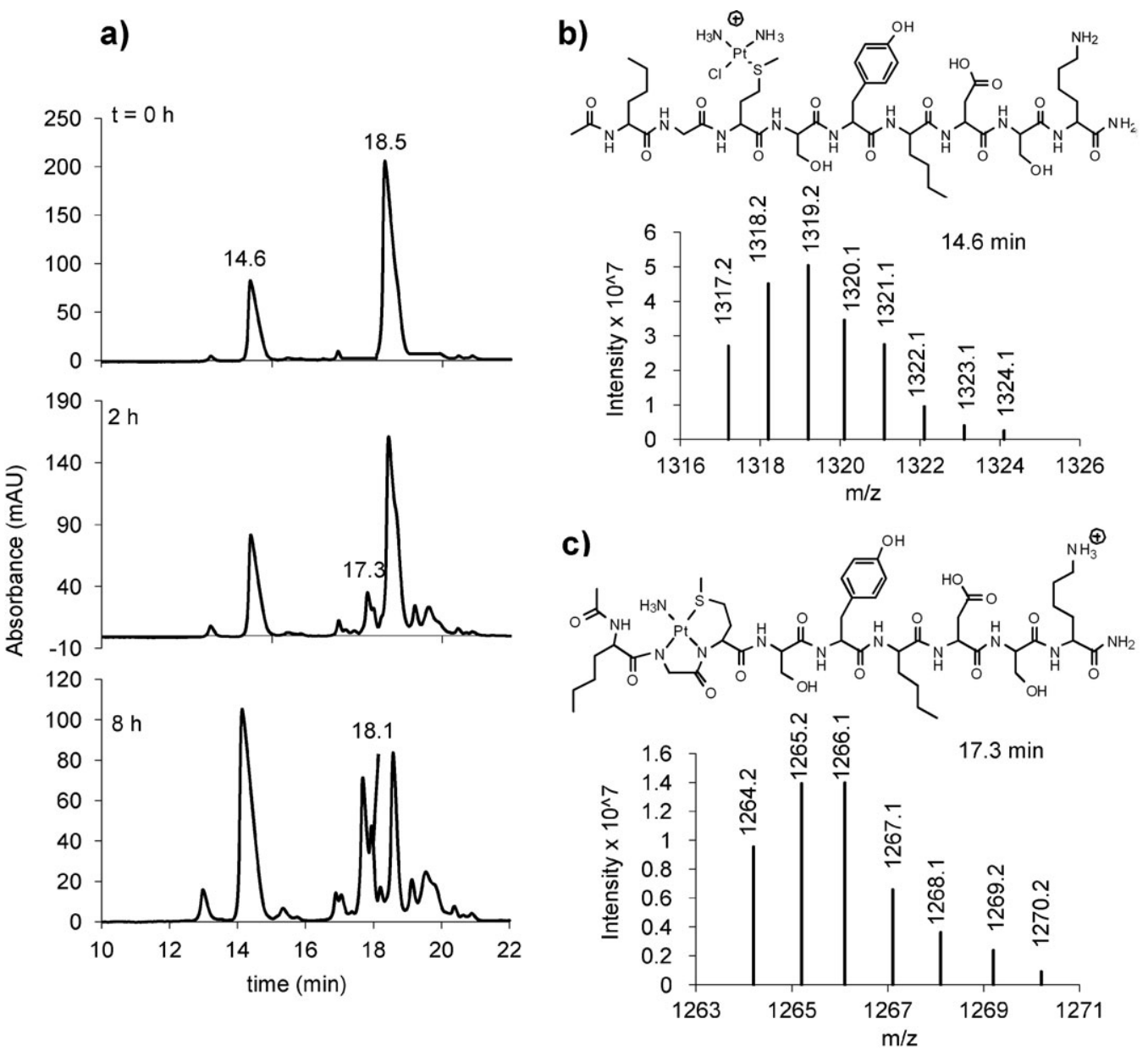

Fig. 2 LC-MS data of peptide P1M9 incubated at $37^{\circ} \mathrm{C}$ with 1 equiv. cisplatin in buffer containing $23.8 \mathrm{mM}$ carbonate, $1.13 \mathrm{mM}$ phosphate, and $100 \mathrm{mM} \mathrm{NaCl}$ at pH 7.4. (a) LC chromatograms taken immediately after mixing $(0 \mathrm{~h})$ and after 2 and $8 \mathrm{~h}$ of incubation. The full-length peptide elutes at $18.5 \mathrm{~min}$. (b) Mass spectrum of the $14.6 \mathrm{~min}$ peak showing the distinct isotope distribution that corresponds to the peptide coordinated to $\left[\mathrm{PtCl}\left(\mathrm{NH}_{3}\right)_{2}\right]^{+}$. (c) Mass spectrum of the 17.3 min peak showing the distinct isotope distribution that corresponds to the peptide coordinated to $\left[\mathrm{Pt}\left(\mathrm{NH}_{3}\right)\right]^{2+}$ via two deprotonated backbone amides and the methionine sulfur. Calculated mass spectra for these species as well the peak at 18.1 min can be found in Fig. S3, ESI. $\dagger$

is necessary for Pt-peptide adduct formation. The speciation of the platinum bound to the single-methionine peptides is different from that observed for the parent P1 reaction with cisplatin in that ammine ligands are retained on Pt. Based on previous findings of the speciation of cisplatin, the chloride ligands are the first to be displaced from cisplatin. The high concentration of chloride used in our reaction buffer likely allows for some retention of chloride to platinum, at least at the early time points.

We encountered some difficulty in determining the products eluting at 13.6, 17.0 and $17.5 \mathrm{~min}$. In order to confirm that these also correspond to platinum-peptide adducts, we introduced DTO to the reaction mixtures. After $24 \mathrm{~h}$ of incubation with the chelator, the LC trace (Fig. S4, ESI $\dagger$ ) showed predominantly one peak corresponding to the apo-peptide. This result confirms that all of the peaks observed previously correspond to $\mathrm{Pt}$-peptide adducts that convert back to the apo-peptide when $\mathrm{Pt}$ is removed. No truncated peptides species were observed, indicating that cisplatin does not induce peptide hydrolysis under these conditions.

\section{hCtr1(39-46 K) (P2) and cisplatin}

Fig. 3 depicts the $\mathrm{LC}$ traces of the reaction of $\mathrm{P} 2$ with cisplatin in a $1: 1$ ratio in our standard reaction buffer at $37^{\circ} \mathrm{C}$. As found for $\mathrm{P} 1$, reactions of $\mathrm{P} 2$ with cisplatin also show a decrease in the amount of apo-peptide observed by LC-MS as incubation time progresses. The apo-peptide elutes at $20.7 \mathrm{~min}$ with $\mathrm{m} / \mathrm{z}$ centered at 1188.8 , and after $24 \mathrm{~h}$ the intensity of this peak significantly diminishes. Within $4 \mathrm{~h}$ of incubation new peaks are observed at $15.3,15.8$, and $18.5 \mathrm{~min}$. The mass corresponding to all of these peaks shows $m / z$ of 1382.6, which is consistent with platinum bound to the peptide with complete loss of its original $\mathrm{Cl}^{-}$and $\mathrm{NH}_{3}$ ligands (Fig. 4). The $\mathrm{Pt}(\mathrm{II})$ could bind to three methionines and a deprotonated amide to give $[(\mathrm{P} 2-\mathrm{H}) \mathrm{Pt}]^{+}$; alternatively, $\mathrm{Pt}(\mathrm{II})$ bound by two methionines, two deprotonated amides, and a proton on Lys would give the same overall formula. The various peaks in the LC trace with the same mass could be due to multiple modes of binding or multiple binding sites, since P2 contains five methionines. 


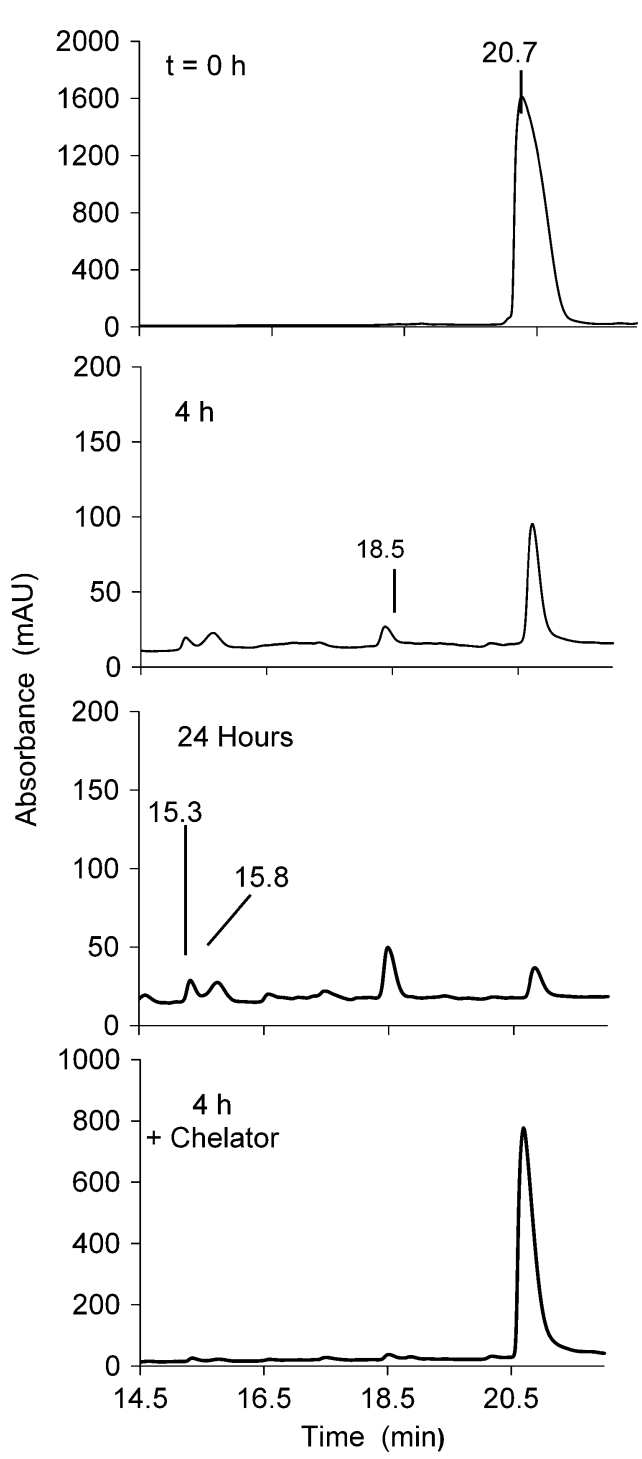

Fig. 3 As incubation time of the reaction between cisplatin and P2 increases from 0 to 4 to $24 \mathrm{~h}$, the peak intensity at $20.7 \mathrm{~min}$, which corresponds to the apo-peptide, decreases from 15-fold. Inversely, as incubation time progresses, platinum adducts with a mass of $1382.6 \mathrm{~m} / \mathrm{z}$ (Fig. 4) appear at 18.4, 15.3, and $15.8 \mathrm{~min}$. Treatment with chelator recovers the apo-peptide signal.

In order to determine reversibility of the P2-Pt adducts, the reaction mixtures were incubated with DTO, but this chelator failed to restore the apo-peptide signal as it had in the P1 studies. Treatment with 10 -fold excess triethylenetetraamine for $8 \mathrm{~h}$, however, was sufficient to regenerate the $20.8 \mathrm{~min}$ apo-peptide peak. This result confirms that no peptide hydrolysis occurs during the cisplatin reactions and also indicates that the 5-methionine $\mathrm{P} 2$ peptide binds Pt(II) tighter than P1.

\section{Carboplatin and P2}

The addition of carboplatin to the $\mathrm{P} 2$ peptide solution yielded much slower adduct formation than its predecessor, cisplatin. As shown in Fig. 5, the apo-peptide eluting at 20.4 min with a mass of $1188.8 \mathrm{~m} / \mathrm{z}$ is the only peak present from 0 to $24 \mathrm{~h}$ of incubation. However, after $48 \mathrm{~h}$ of incubation the intensity of
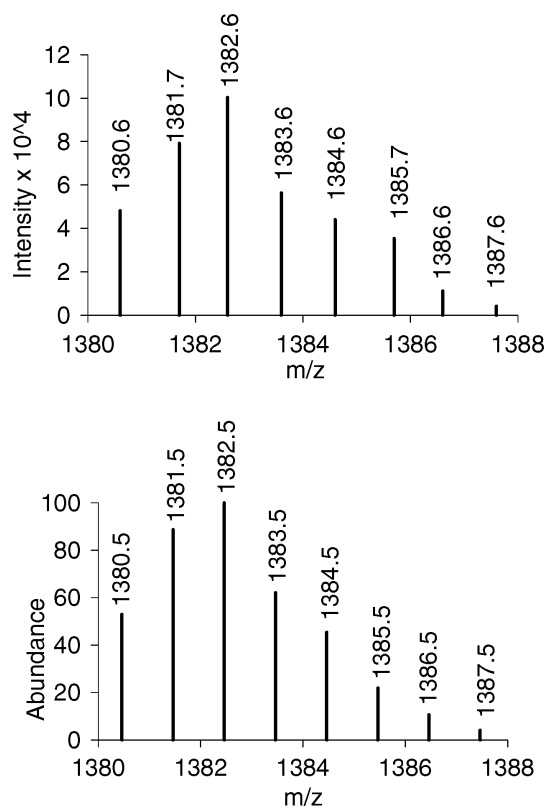

Fig. 4 Mass spectra of $[(\mathrm{P} 2-\mathrm{H}) \mathrm{Pt}]^{+}$species eluting at $15.3,15.8$, and $18.5 \mathrm{~min}$ in Fig. 3. The experimental isotopic pattern of $[(\mathrm{P} 2-\mathrm{H}) \mathrm{Pt}]^{+}$ (top) matches that of the calculated isotopic pattern (bottom).

the apo-peptide peak decreases dramatically and new peaks appear at 15.3, 15.7, 16.6, and $18.4 \mathrm{~min}$ that all provide a mass centered at $1382.6 \mathrm{~m} / z$. These peaks correspond to the same $[(\mathrm{P} 2-\mathrm{H}) \mathrm{Pt}]^{+}$peptide- $\mathrm{Pt}$ adduct observed in the cisplatin reaction, and indicate that the original ammine and cyclobutane dicarboxylate (CBDC) ligands of carboplatin are lost slowly after incubation with P2. After the $48 \mathrm{~h}$ sample was analyzed, triethylenetetraamine was added to the sample in 10-fold excess and incubated for an additional $8 \mathrm{~h}$. The $20.4 \mathrm{~min}$ apo-peptide peak is regenerated without any indication of truncation by-products.

Although peptide-Pt adduct formation was retarded in the presence of carboplatin, there are still strong similarities to the cisplatin reaction in regard to LC/MS analysis. The $48 \mathrm{~h}$ carboplatin sample has matching LC trace patterns with the 4 and $24 \mathrm{~h}$ cisplatin sample (compare Fig. 3 and 5). The platinum adducts formed in both carboplatin and cisplatin reactions are identical, with $\mathrm{Pt}$ (II) undergoing complete loss of all original ligands and solely bound to the $\mathrm{P} 2$ peptide.

\section{Oxaliplatin and P2}

With the introduction of oxaliplatin in a $1: 1$ ratio to a buffered solution of $\mathrm{P} 2$, the presence of the apo-peptide decreases as incubation time progresses, with some apopeptide persisting even after $24 \mathrm{~h}$, as indicated by the peak at $20.3 \mathrm{~min}$ with $\mathrm{m} / \mathrm{z}$ of 1188.8 (Fig. 6). The steady decrease of apo-peptide signal coincides with the appearance of multiple peptide-Pt adducts, the first one appearing within $4 \mathrm{~h}$ and eluting at $16.6 \mathrm{~min}$ with $\mathrm{m} / z$ of 1496.7 . This mass is consistent with a peptide-Pt adduct where the cyclohexyldiamine (CHDA) ligand of oxaliplatin remains coordinated to the metal center (Fig. S5a, ESI $\dagger$ ). A signal at $m / z 1532.7$ also appears, which indicates retention of a chloride in addition to CHDA on Pt (Fig. S5b, ESI $\dagger$ ). After $24 \mathrm{~h}$ of incubation, 

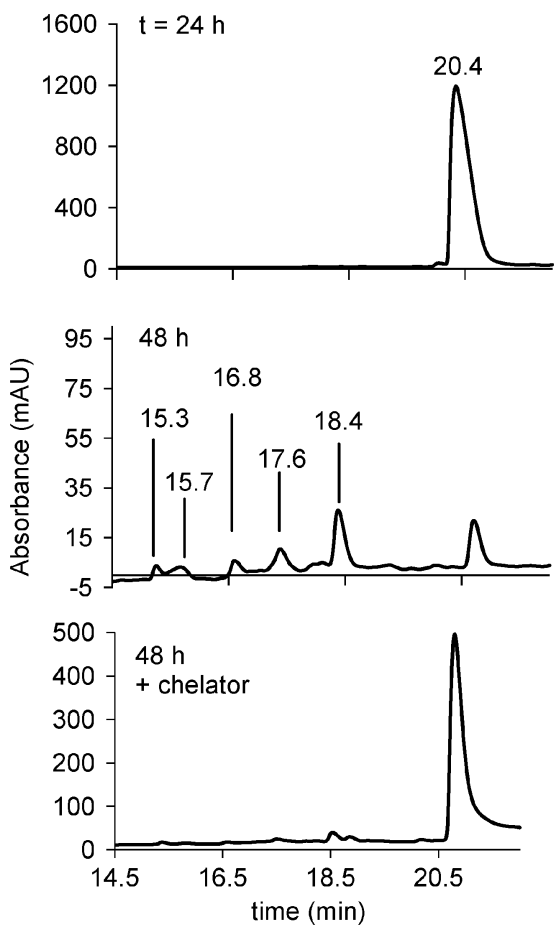

Fig. 5 LC traces of $\mathrm{P} 2+$ carboplatin. No evidence of peptide- $\mathrm{Pt}$ interaction was detected up to $24 \mathrm{~h}$ of incubation, but the peak for the apo-peptide, eluting at $20.8 \mathrm{~min}$, decreases significantly from 24 to $48 \mathrm{~h}$ and platinum-adduct formation is evident. The peaks eluting at 15.3, $15.7,16.6,17.6$, and 18.4 min all correspond to products with $m / z=$ 1382.6 , which is consistent with the $[(\mathrm{P} 2-\mathrm{H}) \mathrm{Pt}]^{+}$adduct observed in the cisplatin reaction.

additional peaks appear at 12.6, 13.5, and $15.4 \mathrm{~min}$. All three peaks correspond to $\mathrm{m} / \mathrm{z}$ of 1802.6 , which correlates to two $\mathrm{Pt}-\mathrm{CHDA}$ units bound to one $\mathrm{P} 2$ peptide, as shown by the mass spectra and chemical drawing representing one possible configuration in Fig. 7. Of the samples investigated in this study, this is the only example of multiple Pt adducts forming on a single peptide.

After $24 \mathrm{~h}$ the sample was treated with 10 -fold excess triethylenetetraamine and incubated for an additional $8 \mathrm{~h}$. Unlike the results observed for cisplatin and carboplatin reactions with $\mathrm{P} 2$ where the apo-peptide was nearly completely recovered following treatment with the chelator, analysis of the reaction mixture with oxaliplatin following chelator treatment reveals little change in the LC trace (Fig. 6). The signal intensity for the apo-peptide peak increases only slightly and the peaks at 12.6, 13.5, 15.4 and 16.3 min persist. These results indicate that the $\mathrm{Pt}(\mathrm{CHDA})$ adducts on $\mathrm{P} 2$ are not easily removed by competitive chelation.

\section{Discussion}

Based on the preceding studies several conclusions can be drawn on the reactivity of platinum drugs with peptide sequences containing Met-rich domains. First, the presence of methionine is necessary for the interaction of Pt drugs with hCtr1 model peptides. This was demonstrated in the lack of Pt-peptide adduct formation in the case of P1-3N and the presence of Pt-peptide adducts in all other studies. Second,

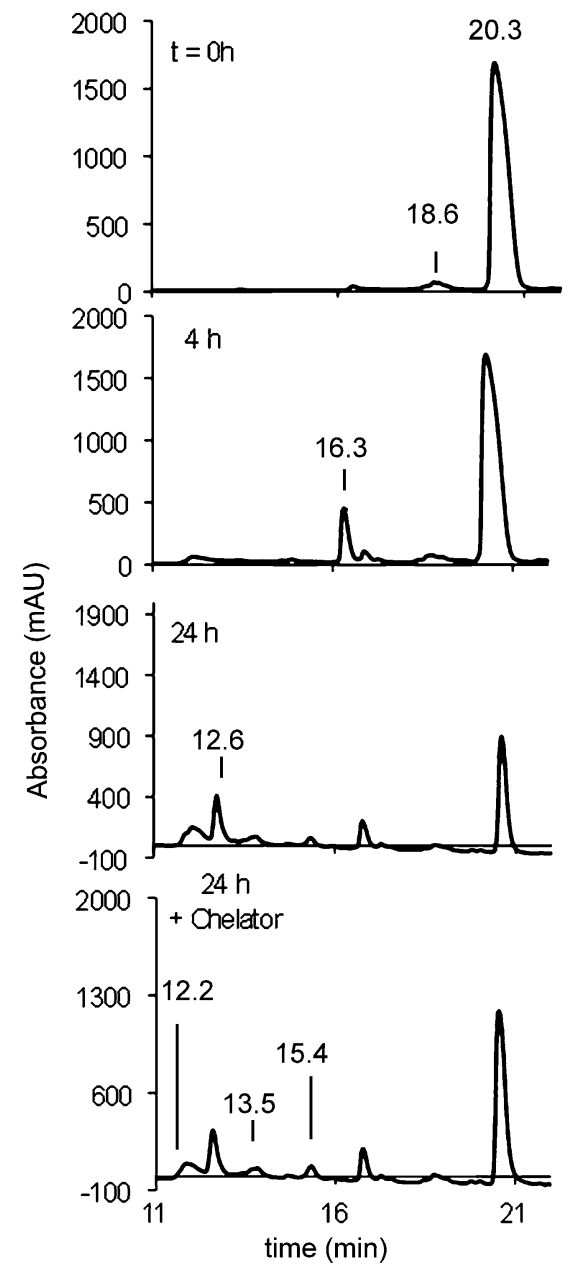

Fig. 6 LC traces of P2 + oxaliplatin showing immediate formation of Pt-adducts. Over the course of $24 \mathrm{~h}$ the UV signal for the apo-peptide at $20.3 \mathrm{~min}$ decreases significantly, while several $\mathrm{Pt}$ adducts appear. The addition of triethylenetetraamine chelator to the $24 \mathrm{~h}$ sample results in an incomplete regeneration of apo-peptide as evidence of Pt-adducts remains.

when only one methionine is present in the peptide, the $\mathrm{Pt}(\mathrm{II})$ retains one or both ammine ligands of cisplatin and carboplatin. In contrast, the multiple-methionine peptides induce loss of all original ligands on cisplatin and carboplatin over time. Recent studies of a methionine-rich peptide based on a yeast $\mathrm{Ctr} 1$ protein with cisplatin also found loss of the original amines and chlorides of cisplatin. ${ }^{62}$ Oxaliplatin is the exception, as its Pt retains the chelating diamine ligand even when bound to the methionine-rich peptide. At the start of this work, one hypothesis was that Pt drugs might act as artificial hydrolases and cleave hCtrl peptides once anchored onto methionine residues. A third conclusion from these studies is that $\mathrm{Pt}$ drugs do not hydrolyze methionine-containing peptides, at least under the tested buffer conditions that mimic extracellular fluid.

One implication of our results is that proteins with single methionine residues are unlikely to alter the speciation of Pt drugs, whereas proteins like Ctrl that have multiple methionines in close proximity can significantly modify the coordination environment of $\mathrm{Pt}$ drugs. The $\mathrm{Pt}$-diamine core is 

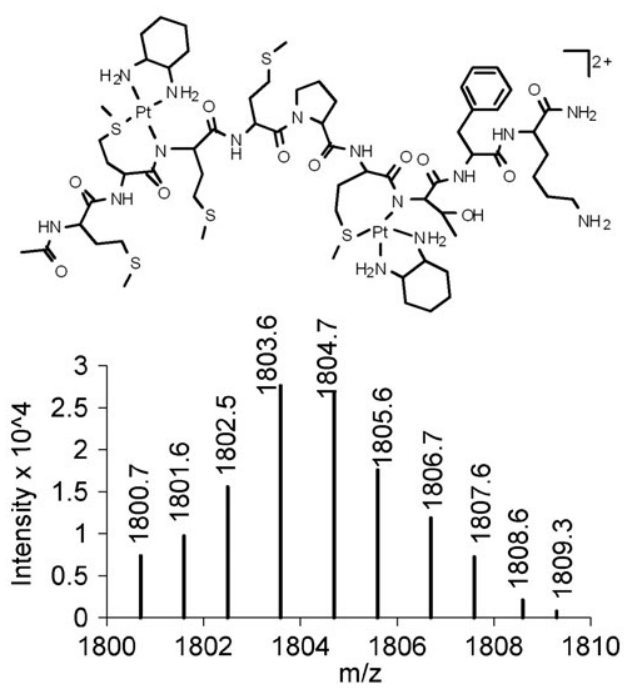

Fig. 7 Structure of one of the possible configurations of the Pt adduct $\mathrm{P} 2+2$ (PtCHDA) with its mass spectrum that appears after $24 \mathrm{~h}$ of incubation at 12.6, 13.9 and 15.4 min in Fig. 6.

presumed to be ultimately responsible for the cytotoxic consequences of cisplatin and carboplatin, therefore complete loss of the carrier ligands before the drugs even enter the cell may severely limit their effectiveness.

The conflicting results found in the literature surrounding the role of $\mathrm{Ctr} 1$ in platinum drug uptake and effectiveness may be due in part to the multiple modes of binding of $\mathrm{Pt}(\mathrm{II})$ complexes observed and described herein. The formation of the cisplatin-peptide adducts is immediate with significant presence within an hour of reactivity. This result suggests that the fraction of administered cisplatin that interacts with extracellular Ctr1 could enter the cell either by direct Ctr1 transport or endocytosis. However, the loss of carrier ligands of cisplatin as a consequence of coordination to the Mets motifs suggests that this fraction of Pt would not be in its cytotoxic form.

An important result from our studies is that Pt-peptide adducts also form from reaction with carboplatin, but on a much slower timescale. The difference in reactivity of cisplatin vs. carboplatin appears to be due to the differing kinetics of ligand exchange. Previous studies have shown that the mechanism of cytotoxicity of carboplatin is the same as cisplatin, but the two drugs differ in the kinetics of their binding to DNA, which directly correlates with the much faster rates of aquation to replace the $\mathrm{Cl}^{-}$ligands of cisplatin vs. the bidentate CBDC ligand of carboplatin. ${ }^{63}$ Although rates of ligand exchange were not directly measured in the current study, the results presented here indicate that ligand exchange initiated by an incoming thioether nucleophile is significantly faster for cisplatin than for carboplatin, as predicted based on the chelating nature of CBDC and known rates of aquation. Upon coordination of the thioether, the rate for subsequent loss of the trans ammine would be similar for both drugs. Peptide-Pt adduct formation was not observed until $48 \mathrm{~h}$ of reaction between carboplatin and P2, which is unlikely to be a clinically relevant timeframe. These results predict that carboplatin is unlikely to interact or be deactivated at the cell surface by Ctr1. Furthermore, in the absence of a direct carboplatin-protein interaction, it seems unlikely that Ctr1 would directly facilitate carboplatin entry in a therapeutic window.

Oxaliplatin, like cisplatin, demonstrates immediate peptide adduct formation, but with very different speciation. In the case of oxaliplatin, the CHDA ligand is retained throughout the course of the reaction and it is the $\operatorname{Pt}(\mathrm{CHDA})^{2+}$ unit that binds to the methionine-rich peptide. This result therefore suggests that if oxaliplatin enters the cell in a Ctr1-mediated pathway, it would retain its important diamine ligand.

In conclusion we have found that interactions of hCtr1 model peptides with $\mathrm{Pt}$ therapies in a biologically relevant buffer result in a variety of Pt-peptide adducts, as a result of the presence of methionine within these sequences. No peptide hydrolysis was observed in these studies indicating that under these conditions the platinum therapies do not act as peptidases. In the case of cisplatin, removal of all original ligands from the platinum center occurs within a few hours of reactivity, whereas loss of ligands from carboplatin happens only after $48 \mathrm{~h}$ of reactivity, and oxaliplatin retains its chelating diamine ligand.

\section{Note added in proof}

Another study of a Ctr1 N-terminal peptide with platinum drugs recently appeared with similar conclusions to the current study. See Z. Wu, Q. Liu, X. Liang, X. Yang, N. Wang, X. Wang, H. Sun, Y. Lu and Z. Guo, J. Biol. Inorg. Chem., 2009, DOI: $10.1007 / \mathrm{s} 00775-009-0576-7$.

\section{Acknowledgements}

We thank the National Science Foundation (Grant CAREER 0449699) for funding these studies. KJF also thanks the Sloan Foundation and the Camille and Henry Dreyfus Foundation, and RJH is grateful for a Duke-Goldman Sachs Research Fellowship from Duke University for undergraduate research.

\section{References}

1 E. R. Jamieson and S. J. Lippard, Chem. Rev., 1999, 99, 2467-2498.

2 D. Wang and S. J. Lippard, Nat. Rev. Drug Discovery, 2005, 4, 307-320.

3 M. D. Hall, M. Okabe, D. W. Shen, X. J. Liang and M. M. Gottesman, Annu. Rev. Pharmacol. Toxicol., 2008, 48, 495-535.

4 F. Arnesano and G. Natile, Coord. Chem. Rev., 2009, 253, 2070-2081.

5 R. Safaei and S. B. Howell, Crit. Rev. Oncol. Hematol., 2005, 53, $13-23$.

6 M. T. Kuo, H. H. W. Chen, I. S. Song, N. Savaraj and T. Ishikawa, Cancer Metastasis Rev., 2007, 26, 71-83.

7 A. K. Holzer, G. Samimi, K. Katano, W. Naerdemann, X. Lin, R. Safaei and S. B. Howell, Mol. Pharmacol., 2004, 66, 817-823.

8 R. Safaei, K. Katano, G. Samimi, W. Naerdemann, J. L. Stevenson, M. Rochdi and S. B. Howell, Cancer Chemother. Pharmacol., 2004, 53, 239-246.

9 S. Ishida, J. Lee, D. J. Theile and I. Herskowitz, Proc. Natl. Acad. Sci. U. S. A., 2002, 99, 14298-14302.

10 C. Rabik, E. Maryon, K. Kasza, J. Shafer, C. Bartnik and M. Dolan, Cancer Chemother. Pharmacol., 2009, 64, 133-142.

11 T. Furukawa, M. Komatsu, R. Ikeda, K. Tsujikawa and S. Akiyama, Curr. Med. Chem., 2008, 15, 3268-3278. 
12 X. Lin, T. Okuda, A. Holzer and S. B. Howell, Mol. Pharmacol., 2002, 62, 1154-1159.

13 A. K. Holzer and S. B. Howell, Cancer Res., 2006, 66, 10944-10952.

14 C. A. Larson, B. G. Blair, R. Safaei and S. B. Howell, Mol. Pharmacol., 2009, 75, 324-330.

15 A. Holzer, G. H. Manorek and S. B. Howell, Mol. Pharmacol., 2006, 70, 1390-1394.

16 P. Kabolizadeh, J. Ryan and N. Farrell, Biochem. Pharmacol., 2007, 73, 1270-1279.

17 I.-S. Song, N. Savaraj, Z. H. Siddik, P. Liu, Y. Wei, C. J. Wu and M. T. Kuo, Mol. Cancer Ther., 2004, 3, 1543-1549.

18 G. L. Beretta, L. Gatti, S. Tinelli, E. Corna, D. Colangelo, F. Zunino and P. Perego, Biochem. Pharmacol., 2004, 68, 283-291.

19 A. K. Holzer, K. Katano, L. W. J. Klomp and S. B. Howell, Clin. Cancer Res., 2004, 10, 6744-6749.

20 Y. Guo, K. Smith and M. J. Petris, J. Biol. Chem., 2004, 279, 46393-46399.

21 S. Puig, J. Lee, M. Lau and D. J. Thiele, J. Biol. Chem., 2002, 277, 26021-26030.

22 S. Puig and D. J. Thiele, Curr. Opin. Chem. Biol., 2002, 6, 171-180.

23 E. B. Maryon, S. A. Molloy, A. M. Zimnicka and J. H. Kaplan, BioMetals, 2007, 20, 355-364.

24 C. J. De Feo, S. G. Aller, G. S. Siluvai, N. J. Blackburn and V. M. Unger, Proc. Natl. Acad. Sci. U. S. A., 2009, 106, 4237-4242.

25 S. G. Aller, E. T. Eng, C. J. De Feo and V. M. Unger, J. Biol. Chem., 2004, 279, 53435-53441.

26 A. Dancis, D. Haile, D. S. Yuan and R. D. Klausner, J. Biol. Chem., 1994, 269, 25660-25667.

27 J. Lee, M. M. O. Peña, Y. Nose and D. J. Thiele, J. Biol. Chem., 2002, 277, 4380-4387.

28 D. Sinani, D. J. Adle, H. Kim and J. Lee, J. Biol. Chem., 2007, 282, 26775-26785.

29 A. Dancis, D. S. Yuan, D. Haile, C. Askwith, D. Eide, C. Moehle, J. Kaplan and R. D. Klausner, Cell, 1994, 76, 393-402.

30 E. Georgatsou, L. A. Mavrogiannis, G. S. Fragiadakis and D. Alexandraki, J. Biol. Chem., 1997, 272, 13786-13792.

31 R. Hassett and D. J. Kosman, J. Biol. Chem., 1995, 270, 128-134.

32 J. Jiang, I. A. Nadas, M. A. Kim and K. J. Franz, Inorg. Chem., 2005, 44, 9787-9794.

33 J. Reedijk, Chem. Rev., 1999, 99, 2499-2510.

34 T. Peleg-Shulman, Y. Najajreh and D. Gibson, J. Inorg. Biochem., 2002, 91, 306-311.

35 T. G. Appleton, J. W. Conner and J. R. Hall, Inorg. Chem., 1988, 27, 130-137.

36 C. D. W. Fröhling and W. S. Sheldrick, J. Chem. Soc., Dalton Trans., 1997, 4411-4420.

37 M. E. Oehlsen, A. Hegmans, Y. Qu and N. Farrell, J. Biol. Inorg. Chem., 2005, 10, 433-442.

38 C. Wilson, M. L. Scudder, T. W. Hambley and H. C. Freeman, Acta Crystallogr., Sect. C: Cryst. Struct. Commun., 1992, 48, 1012-1015.
39 O. Heudi, A. Cailleux and P. Allain, J. Inorg. Biochem., 1998, 71, 61-69.

40 O. Heudi, S. Mercier-Jobar, A. Cailleux and P. Allain, Biopharm. Drug Dispos., 1999, 20, 107-116.

41 S. d. P. Murdoch, J. D. Ranford, P. J. Sadler and S. J. BernersPrice, Inorg. Chem., 1993, 32, 2249-2255.

42 R. E. Norman, J. D. Ranford and P. J. Sadler, Inorg. Chem., 1992, 31, 877-888.

43 M. I. Djuran, D. P. Dimitrijevic, S. U. Milinkovic and Z. D. Bugarcic, Transition Met. Chem., 2002, 27, 155-158.

44 M. I. Djuran, E. L. M. Lempers and J. Reedijk, Inorg. Chem., 1991, 30, 2648-2652.

45 K. Lemma, S. K. C. Elmroth and L. I. Elding, J. Chem. Soc., Dalton Trans., 2002, 1281-1286.

46 E. L. M. Lempers, K. Inagaki and J. Reedijk, Inorg. Chim. Acta, 1988, 152, 201-207.

47 E. L. M. Lempers and J. Reedijk, Inorg. Chem., 1990, 29, 217-222.

48 T. Soldatovic and Z. D. Bugarcic, J. Inorg. Biochem., 2005, 99, $1472-1479$.

49 S. S. G. E. van Boom, B. W. Chen, J. M. Teuben and J. Reedijk, Inorg. Chem., 1999, 38, 1450-1455.

50 F. Arnesano, S. Scintilla and G. Natile, Angew. Chem., Int. Ed., 2007, 46, 9062-9064.

51 F. Arnesano and G. Natile, Pure Appl. Chem., 2008, 80, $2715-2725$.

52 I. E. Burgeson and N. M. Kostic, Inorg. Chem., 1991, 30, 4299-4305.

53 O. Hohage, S. Manka and W. S. Sheldrick, Inorg. Chim. Acta, 2009, 362, 953-966.

54 L.-M. Dutca, K.-S. Ko, N. L. Pohl and N. M. Kostic, Inorg. Chem., 2005, 44, 5141-5146.

55 S. Manka, F. Becker, O. Hohage and W. S. Sheldrick, J. Inorg. Biochem., 2004, 98, 1947-1956.

56 M. Kleine, D. Wolters and W. S. Sheldrick, J. Inorg. Biochem., 2003, 97, 354-363.

57 M. Hahn, M. Kleine and W. S. Sheldrick, J. Biol. Inorg. Chem., 2001, 6, 556-566.

58 P. D. Sadowitz, B. A. Hubbard, J. C. Dabrowiak, J. Goodisman, K. A. Tacka, M. K. Aktas, M. J. Cunningham, R. L. Dubowy and A.-K. Souid, Drug Metab. Dispos., 2002, 30, 183-190.

59 C. R. Centerwall, K. A. Tacka, D. J. Kerwood, J. Goodisman, B. B. Toms, R. L. Dubowy and J. C. Dabrowiak, Mol Pharmacol, 2006, 70, 348-355.

60 P. J. O'Dwyer, J. P. Stevenson and S. W. Johnson, Drugs, 2000, 59, 19-27.

61 H. K. Cho, R. M. Lush, D. L. Bartlett, H. R. Alexander, P. C. Wu, S. K. Libutti, K. B. Lee, D. J. Venzon, K. S. Bauer, E. Reed and W. D. Figg, J. Clin. Pharmacol., 1999, 39, 394-401.

62 C. Sze, G. Khairallah, Z. Xiao, P. Donnelly, R. O'Hair and A. Wedd, J. Biol. Inorg. Chem., 2009, 14, 163-165.

63 R. J. Knox, F. Friedlos, D. A. Lydall and J. J. Roberts, Cancer Res., 1986, 46, 1972-1979. 